\title{
INFLUENCE OF EXOGENOUS NITRIC OXIDE ON IMPROVING DROUGHT TOLERANCE OF SEVEN HYBRIDS AND SEVEN INBREDS OF MAIZE
}

(Received:13.7.2009)

\author{
By \\ H. M. Rashad and F. M. Abou-Elalla* \\ Department of Agricultural Botany, Plant Physiology Division \& * Department of Agricultural \\ Biochemistry, Faculty of Agriculture, Cairo University, Giza Egypt
}

\begin{abstract}
Nitric oxide (NO) is an active molecule involved in the mediation of various biotic and abiotic stresses inducing physiological responses in the plants. In the present study, the effect of sodium nitroprusside (SNP) presoaking, as a donor of NO, on the antioxidant system of seven inbreds and seven hybrids of maize under drought stress was examined compared with the control. The activities of some antioxidant enzymes [Glutathione reductase (GR, EC1.6.4.2), Superoxide dismutase (SOD, EC1.15.1.1), Glutathione peroxidase (GPx, EC 1.11.1.9) and Catalase (CAT, EC 1.11.1.6], were assayed. Also, the levels of ascorbate, endogenous nitric oxide, chlorophyll, osmolality contents were determined in the leaves of maize subjected to water deficit. Hybrid and inbred seeds were planted in three different locations (BeniSwief T1, EL-Behara T2, and Giza T3). The drought treatments were estimated as 100, 80, and 65\% of the field capacity and after 10,14 and 18 days of drought stress in all locations. The results showed that although SNP induced increases in GR ,GPX and CAT activities in drought-stressed leaves of maize, while SOD activity remained unchanged (14 and 18 DAS). The levels of osmolality and chlorophyll remained unchanged, while the levels of total ascorbate, and nitric oxide were increased in SNP-treated leaves. The results also indicated that the levels of antioxidant enzyme activities, ascorbate and nitric oxide in SNP-treated depended on the NO content, cultivars and the cultivated locations. These might contribute to the differential prevention of oxidative damage in plants exposed to drought stress.
\end{abstract}

Key words: antioxidant enzymes, drought stress, maize leaves, nitric oxide, sodium nitroprosside $(S N P)$.

Abbreviations:

(AsA) Ascorbate, ABA: Abcisic acid, CAT: Catalase , DAS: Day after sowing DTT Dithiothreitol, GPx: Glutathione Peroxidase, GR: Glutathione Reductase, ROS: Reactive Oxygen Species, SNP: Sodium Nitroprusside, SOD: Superoxide Dismutase.

\section{INTRODUCTION}

Drought stress is the most important environmental factor limiting crop productivity in many cultivated areas of the world. At the wholeplant level, the effect of water stress is usually perceived as a decrease in the photosynthesis process and growth rate. At the molecular level, the negative effect is associated with oxidative damage to the plant cell produced by osmotic stress, due to imbalance between production of Reactive Oxygen Species (ROS) and antioxidant defenses (Sharma and Dubey, 2005 and Hu et al. 2006 ). Accordingly, the high capacity to detoxify reactive oxygen species contributes to increasing drought tolerance of plants (Bowler et al., 1992, and $\mathrm{Li}$ et al., 1998). During salinity stress, another plant strategy that may confer tolerance stress is the rapid accumulation of compatible osmolytes such as proline and glycinebetain (Bray, 1993, Maggio et al., 2002 and Akataş et al., 2007).

Acclimation of plants to drought stress is often associated with increased levels of ROS, such as superoxide anion $\left(\mathrm{O}_{2}{ }^{-}\right)$, hydrogen peroxide $\left(\mathrm{H}_{2} \mathrm{O}_{2}\right)$, hydroxyl radical $\left(\mathrm{HO}^{-}\right.$) (Smirnoff 1993, and Chaves et al., 2003). ROS are products of aerobic metabolism and their production is enhanced during drought conditions through the disruption of the electron transport system and oxidizing metabolic activities occurring in the chloroplasts, mitochondria and microbodies (Asada, 1999 and Van Breusegem et al., 2001). Excessive levels of ROS damage to cellular structures and macromolecules cause photoinhibition of 
photosynthetic apparatus (Smirnoff, 1993 ) but the production and accumulation of ROS activate multiple defense responses, thus having also a positive role (Van Breusegem et al., 2001 and Vranová et al., 2002).

Under non-stressful conditions, ROS are efficiently eliminated by non- enzymatic and enzymatic antioxidants, whereas during drought conditions the production of ROS exceeds the capacity of the antioxidative systems to remove them, causing oxidative stress ( Smirnoff, 1993 and Noctor and Foyer, 1998) The antioxidant non-enzymatic system includes ascorbate and glutathione, two constituents of the antioxidative ascorbate-glutathione cycle which detoxify $\mathrm{H}_{2} \mathrm{O}_{2}$ in the chloroplasts (Asada, 1999) and are located within both the cell and the apoplast (Horemans et al ., 2000 and Foyer et al., 2001). Ascorbate (AsA) is a major primary antioxidant synthesized on the inner membrane of the mitochondria which reacts chemically with $\mathrm{O}^{2-}, \mathrm{HO}^{-}$and thiol radical (Asada, 1999 and Noctor and Foyer, 1998) and acts as the natural substrate of many plant peroxidases (Mehlhorn et al., 1996). Moreover, AsA is involved in other functions such as plant growth, gene regulation, modulation of some enzymes and redox conditions. ROS are efficiently eliminated by non-enzymatic and regulation of membrane-bound antioxidant compounds (Noctor and Foyer 1998 and Horemans et al., 2000).

Nitrite oxide (NO) is a lipophilic molecule that diffuses through membranes. Although first described as a signal molecule in animals, accumulating evidence shows that $\mathrm{NO}$ is an important signal molecule involved in plant response to biotic and abiotic stresses (Delledonne et al., 1998; Uchida et al., 2002 and Yang et al., 2006). Some researchers applied exogenous NO directly to plants to elucidate the role of $\mathrm{NO}$ in plant growth and stress tolerance. The results showed that the application of exogenous NO confers resistance to salt (Uchida et al., 2002), heavy metals (Hsu and Kao, 2004), chilling , (Neill et al., 2003) and ultraviolet- $\beta$ radiation stresses (Shi et al., 2005). Although it has been shown that exogenous application of NO donors can enhance adaptive plant responses against drought stress through inducing stomatal closure (Mata and Lamattina , 2001), the mechanism of drought tolerance induced by $\mathrm{NO}$ is not yet clear till now. Additionally, $\mathrm{NO}$ is itself a reactive nitrogen species and its effects on different types of cells have proved to be either protective or toxic, depending on its concentration and on the situation. In the systems where toxicity is incurred predominantly from ROS, NO may act as a chain breaker and thus limit damage (Lipton et al., 1993 ).

In this study, SNP (sodium nitroprusside) was used as NO donor to alleviate oxidative damage of drought stress. The aim of this work was to study the changes of antioxidant enzyme activities (GR, SOD, CAT, and GPx), the level of some antioxidant compounds (ascorbate and nitric oxide), osmolality and chlorophyll content after treatment with SNP in the leaves of seven hybrids and seven inbreds of maize grown under water shortage followed by a rewatering in three different locations of Egypt.

\section{MATERIALS AND METHODS \\ 2.1. Plant material and experimental design}

The present investigation was conducted at three experimental locations of Egypt (BeniSwief, Giza and EL-Behara. The experimental period started on May 3, 7 and 15, 2006, in the three locations, respectively. The plant material included seven interspecific hybrids (Sc120, Sc129, Sc155, Twc310, Twc 311, TWC314, and TWC352.) and seven specific inbreds of maize ; (Sd34, Gz 603, Gz629 , Gm128 , Gm30, Gm 1021 and Gm1001). There are intership between hybrids and inbreds of maize. The plants were subjected to drought stress at 100, 80 and $65 \%$ of the a field capacity irrigation interval $(10,14$ and 18 days in Giza, Beni-Swief and El-Behara). All grain samples were supplied by Agricultural Agronomy Research Center, Giza (Maize Improving Project) and sterilized with $15 \%$ (V/V) $\mathrm{H}_{2} \mathrm{O}_{2}$ solution and soaked in sodium nitroprosside solution (SNP) $\quad(0.28 \mathrm{~g} / \mathrm{l})$ for $24 \mathrm{~h}$ before planting. Soaking treatment was activated by foliar spraying with SNP solution at 30 DAS. All hybrid and inbred plants were divided into three drought groups in Giza, Bani-Swief, and ElBehara. the first group was irrigated after 10 days (control), the second group was irrigated after 14 and the third group was irrigated after 18 days interval from planting. The control seeds were soaked in water. Fresh leaves of all hybrids and inbreds were collected after 45 DAS and used in all determinations. The present experiment was subjected to random block design.

\subsection{Enzyme extraction and assay}

Fresh leaves (1g) were washed and homogenized in $5 \mathrm{ml}$ of $0.1 \mathrm{M}$ potassium phosphate buffer ( $\mathrm{pH}$ 6.8) containing $0.1 \mathrm{mM}$ EDTA and $100 \mathrm{mg}$ of polyvinyl pirolidone (PVP). The homogenate was centrifuged at $15,000 \mathrm{~g}$ for 
$20 \min$ at $4^{\circ} \mathrm{C}$ and the supernatant was immediately used for the following enzyme assays: SOD, GR,CAT, and GPx. Total SOD activity was assayed by monitoring the inhibition of the photochemical reaction of nitro blue tetrazolium (NBT) according to the method described by Beyer and Fridowich (1987). One unit of SOD activity was defined as the amount of enzyme that was required to cause $50 \%$ inhibition of the reduction of NBT as monitored at $560 \mathrm{~nm}$. CAT activity was assayed by measuring the rate of decomposition of $\mathrm{H}_{2} \mathrm{O}_{2}$ at $240 \mathrm{~nm}$, (using a Thermo-scientific-UK spectrophotometer). within $1 \mathrm{~min}$ as described by Aebi. (1983). The $3 \mathrm{ml}$ reaction solution contained $15 \mathrm{mM} \mathrm{H}_{2} \mathrm{O}_{2}, 50 \mathrm{mM}$ phosphate buffer ( $\mathrm{pH}$ 7.0) The reaction was initiated by adding enzyme extract. GR activity was measured by following the change in $340 \mathrm{~nm}$ as oxidized glutathione (GSSG)-dependent oxidation of NADPH, according to Carlberg and Mannervik (1985). GPx activity was determined according to the method of Paglia and Valentine (1967). GPx catalyses the oxidation of glutathione by cumene hydroperoxide in the presence of glutathione reductase and NADPH. The oxidized glutathione is immediately converted to reduced form with a concomitant oxidation of NADPH to NAD+. The decrease in absorbance at $340 \mathrm{~nm}$ was measured at $37^{\circ} \mathrm{C}$.

\subsection{Ascorbate levels}

Ascorbate level was determined using the method described by Foyer et al. (1983). Washed fresh leaves $(1 \mathrm{~g})$ were homogenized in $5 \mathrm{ml}$ of trichloroacetic acid (TCA) then the homogenate was centrifuged at $15,000 \mathrm{~g}$ for $20 \mathrm{~min}$ at $4{ }^{\circ} \mathrm{C}$ and the supernatant was immediately used for the determination of ascorbate content. A $0.5 \mathrm{~g}$ aliquot of leaves was homogenized in $1.0 \mathrm{ml}$ of ice-cold $2.5 \mathrm{~N}$ perchloric acid $\left(\mathrm{HClO}_{4}\right)$. The homogenate was filtered through three layers of cheesecloth (Miracloth) and then centrifuged at $15,000 \mathrm{~g}$ for $5 \mathrm{~min}$. For measuring of total ascorbate, $300 \mathrm{ml}$ of neutralized extract were added to $1.2 \mathrm{ml}$ of a reaction mixture containing $20 \mathrm{mM}$ dithiothreitol (DTT) in $50 \mathrm{mM}$ Hepes$\mathrm{KOH}, \mathrm{pH}$ 7.0. After incubation for $10 \mathrm{~min}$ at $25^{\circ} \mathrm{C}$ in a water bath, $100 \mathrm{ml}$ of $0.5 \mathrm{M} \mathrm{N}$ ethylmaleimide were added to remove DTT. The reaction was started with the addition of five units of ascorbate oxidase.

\subsection{Nitric oxide content}

Nitric oxide content was determined using the method described by Hu et al. (2003) with slight modifications as follows, leaf samples $(0.6 \mathrm{~g})$ were ground in a mortar and pestle in $3 \mathrm{ml}$ of 50
$\mathrm{mM}$ acetic acid buffer $(\mathrm{pH} 3.6$, containing $4 \%$ zinc diacetate). The homogenates were centrifuged at $10000 \mathrm{~g}$ for $15 \mathrm{~min}$ at $4^{\circ} \mathrm{C}$. The supernatant was collected. The pellet was washed with $1 \mathrm{ml}$ of extraction buffer and centrifuged as before. The two supernatants were combined and $0.1 \mathrm{~g}$ of charcoal was added. After vortex and filtration, the filtrate was leached and collected. The mixture of $1 \mathrm{ml}$ of filtrate and $1 \mathrm{ml}$ of the Greiss reagent was incubated at room temperature for $30 \mathrm{~min}$. Absorbance was determined at 540 $\mathrm{nm}$. NO content was calculated by comparison to a standard curve of $\mathrm{NaNO}_{2}$.

\subsection{Chlorophyll contents}

Chlorophyll contents in a leaf sample was determined according to the method of Wintermans and De Mots (1965).

\subsection{Leaf osmolality}

For the determining of leaf osmolality, leaf extracts were prepared from the $3^{\text {rd }}$ leaf by using Jones and Turner (1978) method. The osmolality was determined by using a cryoscopic osmometer (Osmomat 030 - Germany).

\subsection{Statistical analysis}

Statistical analysis of the data was performed using Statistica Programme. Duncan's Multiple Range Test was used to determine significant differences of the means at a 5\% level. Different letters (a-d) indicated significant differences at $\mathrm{P}$ $\leq 0.05$ level among treatments according to Duncan's multiple range test.

\section{RESULTS}

Activities of antioxidant enzymes of maize hybrids and inbreds after 14 and 18 DAS

In the present investigation, all data with rewatering 14 and 18 DAS are relative to the control result (10 days) Effect of exogenous NO on antioxidant enzymes activities (GR, GPx, CAT and SOD) of seven hybrids and seven inbreds presoaked with SNP and rewatering after 14 and 18 days is shown in Tables (1, 2, 3, and 4).

\subsection{Antioxidant enzymes of hybrids (after 14 DAS ).}

Effect of exogenous NO on antioxidant enzymes activities of seven hybrids presoaked with SNP and rewatering after 14 DAS is shown in Table (1). The results show that the activities of CAT, GR and GPx were significantly increased in all three locations after treatment with SNP compared to the control, but the activity of SOD was not affected. Also, it was observed that the activities of GR, GPx, and CAT in T2, T3 were higher than their activities in T1 location. These results showed that the activity of SOD remained 
Table (1): Effect of SNP presoaking on antioxidant enzyme activities of hybrids of maize leaves (14 days, relative to 10 days).

\begin{tabular}{|c|c|c|c|c|c|}
\hline \multirow{2}{*}{$\begin{array}{c}\text { Enzyme } \\
\text { Activity } \\
\text { ( U/I) }\end{array}$} & \multirow{2}{*}{ Control } & \multicolumn{3}{|c|}{ SNP-Treatment } & \multirow{2}{*}{ L.S.D } \\
\cline { 3 - 6 } & & $\mathrm{T} 1$ & $\mathrm{~T} 2$ & $\mathrm{~T} 3$ & \\
\hline GR & $138 \mathrm{c}$ & $151 \mathrm{~b}$ & $442 \mathrm{a}$ & $449 \mathrm{a}$ & 9.9 \\
GPx & $77 \mathrm{~d}$ & $122 \mathrm{c}$ & $150 \mathrm{~b}$ & $162 \mathrm{a}$ & 11 \\
CAT & $65 \mathrm{~d}$ & $146 \mathrm{~b}$ & $284 \mathrm{a}$ & $130 \mathrm{c}$ & 9.8 \\
SOD & $71 \mathrm{a}$ & $61 \mathrm{~b}$ & $66 \mathrm{a}$ & $70 \mathrm{a}$ & 4.4 \\
\hline
\end{tabular}

T1: Beni-Swief location ,T2 EL-Behara location .T3 Giza

unchanged with SNP treatment in all three locations (Table 1).

\subsection{Antioxidant enzyme of inbreds (after 14 DAS)}

Effect of exogenous NO on antioxidant enzymes activities of seven inbreds presoaked with SNP and rewatering 14 DAS was studied. The results in (Table 2) show that the activities of the three enzymes (GR, GPx, and CAT) were increased after treatment with SNP in all locations but SOD activity was not affected compared to the control. The results indicate that the highest activities of GR and CAT were found in ELBehara (T2) while the highest activity of GPx was in Beni-Swief location. It was also noticed that the activity of SOD remained unchanged with SNP treatment in all three locations (Table 2).

Table (2): Effect of SNP presoaking on antioxidant enzyme activities of inbred of maize leaves (14 days, relative to 10 days).

\begin{tabular}{|c|c|c|c|c|c|}
\hline \multirow{2}{*}{$\begin{array}{c}\text { Enzyme } \\
\text { activity } \\
\text { (U/I) }\end{array}$} & \multirow{2}{*}{ Control } & \multicolumn{3}{|c|}{ SNP-Treatment } & \multirow{2}{*}{ L.S.D } \\
\cline { 3 - 5 } GR & $96 \mathrm{c}$ & $207 \mathrm{~b}$ & $335 \mathrm{a}$ & $212 \mathrm{~b}$ & 17 \\
GPx & $38 \mathrm{c}$ & $128 \mathrm{a}$ & $70 \mathrm{~b}$ & $124 \mathrm{a}$ & 10 \\
CAT & $66 \mathrm{c}$ & $140 \mathrm{~b}$ & $190 \mathrm{a}$ & $183 \mathrm{a}$ & 9 \\
SOD & $71 \mathrm{a}$ & $72 \mathrm{a}$ & $63 \mathrm{a}$ & $71 \mathrm{a}$ & 8 \\
\hline
\end{tabular}

T1: Beni-Swief location,T2 EL-Behara location .T3 Giza.

\subsection{Antioxidant enzyme of hybrids (after 18 DAS) \\ Effect of exogenous NO on antioxidant}

enzyme activities of hybrids presoaked with SNP and rewatered 18 DAS is shown in Table (3). The results show that the activities of three enzymes (GR, GPx and CAT) were significantly increased after treatment with SNP in both T2 and T3 locations but SOD activity was not affected compared with the control. The results show that GR activity increased in all three locations while the higher activities of GPX and CAT were in T3 location. Also from these results, it is noticed that the activity of SOD remained unchanged with SNP treatment

Table (3): Effect of SNP presoaking on antioxidant enzyme activities of hybrids of maize leaves (18 days, relative to 10 days).

\begin{tabular}{|c|c|c|c|c|c|}
\hline \multirow{2}{*}{$\begin{array}{c}\text { Enzyme } \\
\text { Activity } \\
\text { ( U/I) }\end{array}$} & Control & T1 & T2 & T3 & \multirow{2}{*}{ LSD } \\
\cline { 3 - 5 } GR & $187 d$ & $434 \mathrm{a}$ & 387 & $250 \mathrm{c}$ & 10.7 \\
& & & & & \\
GPX & $90 \mathrm{c}$ & $109 \mathrm{~b}$ & 105 & $145 \mathrm{a}$ & 12 \\
CAT & $97 \mathrm{c}$ & $260 \mathrm{~b}$ & 102 & $280 \mathrm{a}$ & 10 \\
& & & & \\
SOD & $72 \mathrm{a}$ & $61 \mathrm{~b}$ & $70 \mathrm{a}$ & $70 \mathrm{a}$ & 6.8 \\
\hline
\end{tabular}

T1: Beni-Swief location ,T2 EL-Behara location .T3 Giza.

in all three locations (Table 3).

\subsection{Antioxidant enzymes of inbred maize (after 18 DAS)}

Effect of exogenous NO on antioxidant enzyme activities of seven inbreds presoaked with SNP and rewatered after 18 days was studied and the results are shown in (Table 4). The data clarify that the activities of the three enzymes (GR, GPx, and CAT) were increased after presoaking with SNP in all locations but SOD activity was not affected. It can be concluded that the higher activities of GR and CAT were in T2 but the higher activity of GPx was found in T1 and T3. It was also observed that the activity of SOD remained unchanged with SNP treatment in all hybrids and inbreds in all locations (Table 4).

\subsection{Nitric oxide content}

Endogenous nitric oxide content was determined in all hybrids and inbreds (Table 5 ). The effect of SNP treatment on endogenous nitric oxide content of all hybrids and inbreds has been detected. The results show that nitric oxide 
Table (4): Effect of SNP presoaking on antioxidant enzyme activities of inbred maize leaves ( 18 days, relative to 10 days ).

\begin{tabular}{|c|c|c|c|c|c|}
\hline \multirow[b]{2}{*}{$\begin{array}{c}\text { Enzyme } \\
(\mathrm{U} / \mathbf{l})\end{array}$} & \multirow[b]{2}{*}{ Control } & \multicolumn{3}{|c|}{ SNP-Treatment } & \multirow[b]{2}{*}{ LSD } \\
\hline & & T1 & T2 & T3 & \\
\hline GR & $138 \mathrm{c}$ & 234b & $242 b$ & $389 a$ & 13 \\
\hline GPx & $86 c$ & 148a & $100 b$ & $97 b$ & 10 \\
\hline CAT & 73d & $471 \mathrm{a}$ & $135 c$ & $193 b$ & 10 \\
\hline SOD & $72 a$ & $72 a$ & $61 b$ & $70 a$ & 7 \\
\hline
\end{tabular}

content increased in SNP-treated leaves compared to the untreated leaves in all locations (T1,T2 and T3) and all inbreds at 14 and18 DAS . There was an increase in nitric oxide content in all hybrids except in T2 (14 days). leaves of both hybrids and inbreds in the three locations (T1,T2 and T3). In hybrids the highest level of asworbate content was detected in T3 location while the highest concentration of ascorbate in the inbreds was in $\mathrm{T} 2$ and $\mathrm{T} 3$ locations.

\subsection{Osmolality}

Leaf osmolality concentration $(\mu \mathrm{M} \mathrm{Osmol} / \mathrm{Kg})$ was determined in all hybrids and inbreds of maize (Table 7) as physiological indicators. The osmolality in hybrids 14 DAS was increased in SNP-treatment in T2 by $25 \%$ compared to the control, and $\mathrm{T} 3$ by $37 \%$ but it remained unchanged in $\mathrm{T} 1$. There was a slight increase in osmolality in the hybrids with 18 DAS except at T2 ( increase by 19\%). The treatment with SNP prevented the decrease in osmolality caused by drought stress especially in hybrids of T3 location. The available data of inbreds were only detected in T1 where, SNP effect on osmolality was not significant compared to the control. However,

Table (5) Effect of SNP presoaking on endogenous nitric oxide content in leaves of both hybrids and inbred of maize leaves.

\begin{tabular}{|c|c|c|c|c|c|c|c|c|c|c|c|c|c|c|c|}
\hline \multicolumn{16}{|c|}{ Endogenous nitric oxide content ( $\mu \mathrm{mol} / \mathrm{L}$ ) } \\
\hline \multicolumn{4}{|c|}{ Hybrids (14 days ) } & \multicolumn{4}{|c|}{ Hybrids (18 days) } & \multicolumn{4}{|c|}{ Inbred (14 days) } & \multicolumn{4}{|c|}{ Inbred (18 days) } \\
\hline $\mathbf{C}$ & T1 & $\mathbf{T} 2$ & $\mathbf{T 3}$ & $\mathbf{C}$ & T1 & $\mathbf{T} 2$ & T3 & $\mathbf{C}$ & T1 & $\mathbf{T} 2$ & $\mathbf{T 3}$ & $\mathbf{C}$ & T1 & $\mathbf{T 2}$ & $\mathbf{T 3}$ \\
\hline $10 \mathbf{a}$ & $43 c$ & $67 \mathrm{~b}$ & $77 a$ & $20 \mathrm{~d}$ & $53 \mathrm{c}$ & $79 b$ & 91a & $27 d$ & $53 \mathrm{c}$ & $74 \mathrm{~b}$ & 92a & $28 \mathrm{c}$ & $38 \mathrm{c}$ & $53 b$ & $85 a$ \\
\hline
\end{tabular}

C: Control T1: Beni-Swief location ,T2 EL-Behara location. $\quad$ T3 Giza.., LSD ( Hybrids 14 day $)=8$

LSD $($ Hybrids 18 day $)=9$, LSD $($ Inbreds 14 day $)=11 \quad$ LSD $($ Inbreds 18 day $)=12$

Table (6): Effect of SNP presoaking on ascorbate content in leaves of both hybrids and inbreds of maize leaves

\begin{tabular}{|c|c|c|c|c|c|c|c|c|c|c|c|c|c|c|c|}
\hline \multicolumn{16}{|c|}{ Ascorbate Content $(\mu \mathrm{mol} / \mathrm{L})$} \\
\hline \multicolumn{4}{|c|}{ Hybrids (14 days) } & \multicolumn{4}{|c|}{ Hybrids (18 days) } & \multicolumn{4}{|c|}{ Inbred (14 days) } & \multicolumn{4}{|c|}{ Inbred (18 days) } \\
\hline $\mathbf{C}$ & $\mathbf{T 1}$ & $\mathbf{T} 2$ & $\mathbf{T 3}$ & $\mathbf{C}$ & $\mathbf{T 1}$ & $\mathbf{T} 2$ & $\mathbf{T 3}$ & $\mathbf{C}$ & $\mathbf{T 1}$ & $\mathbf{T 2}$ & T3 & $\mathbf{C}$ & $\mathbf{T 1}$ & $\mathbf{T} 2$ & T3 \\
\hline 23 & 66 & 37 & 72 & 19 & 55 & 42 & 73 & 19 & 40 & 76 & 58 & 32 & 54 & 46 & 58 \\
\hline b & $\mathbf{a}$ & $\mathbf{b}$ & $\mathbf{a}$ & c & $\mathbf{b}$ & $\mathbf{b}$ & $\mathbf{a}$ & d & c & $\mathbf{a}$ & $\mathbf{b}$ & $\mathbf{b}$ & c & c & c \\
\hline
\end{tabular}

\subsection{Ascorbate content}

Ascorbate content was determined in all hybrids and inbreds (Table 6). The results refer that there was an increase in ascorbate content in SNP-treated leaves compared to the untreated there was slight increase with SNP treatment in inbreds. All results in the present research are presented as mean values for inbreds and hybrids. 3.8. Chlorophyll content 
Total chlorophyll content was determined in the leaves of all hybrids and inbreds of maize (Table 8). The results show that there was no increase in chlorophyll content after treatment with SNP compared to the control in all inbreds. In the hybrids there was a significant increase in chlorophyll content in T1 location and a decrease in T2 at 14 and18 DAS. and over expression of ROS in maize leaves which in turn caused exacerbation of lipid peroxidation and depression of photosynthesis. Application of SNP (NO donor) suppressed decline in GR, GPx and CAT activities and increase in $\mathrm{O}^{2-}$ production under drought stress (Tables 1, 2, 3 and 4). Therefore, lipid peroxidation was evidently inhibited.

Table (7): Effect of SNP presoaking on osmolality in leaves of both hybrids and inbreds of maize

\begin{tabular}{|c|c|c|c|c|c|c|c|c|c|c|c|}
\hline \multicolumn{12}{|c|}{ Osmolality ( $\mu \mathrm{mol}$ osmol/kg) } \\
\hline \multicolumn{4}{|c|}{ Hybrids (14 days ) } & \multicolumn{4}{|c|}{ Hybrids (18 days) } & \multicolumn{2}{|c|}{ Inbreds (14 } & \multicolumn{2}{|c|}{ Inbreds (18 days) } \\
\hline $\mathbf{C}$ & $\mathbf{T 1}$ & $\mathbf{T 2}$ & $\mathbf{T 3}$ & $\mathbf{C}$ & T1 & $\mathbf{T 2}$ & $\mathbf{T 3}$ & $\mathbf{C}$ & T1 & $\mathbf{C}$ & $\mathbf{T 1}$ \\
\hline 1.6a & $1.6 a$ & $\mathbf{2 a}$ & $2.2 \mathrm{a}$ & $1.6 a$ & 1.8a & 2.1a & $1.7 \mathrm{a}$ & $1.6 a$ & $2 a$ & $1.6 a$ & $1.9 a$ \\
\hline
\end{tabular}

C : Control, T1: Beni-Swief location ,T2: EL-Behara location .T3 : Giza.

LSD $($ all Hybrids and Inbreds $)=0.7$ LSD $($ all Hybrids and Inbreds $)=0.7$

Table (8): Effect of SNP presoaking on Chlorophyll content in both hybrids and inbreds of maize leaves.

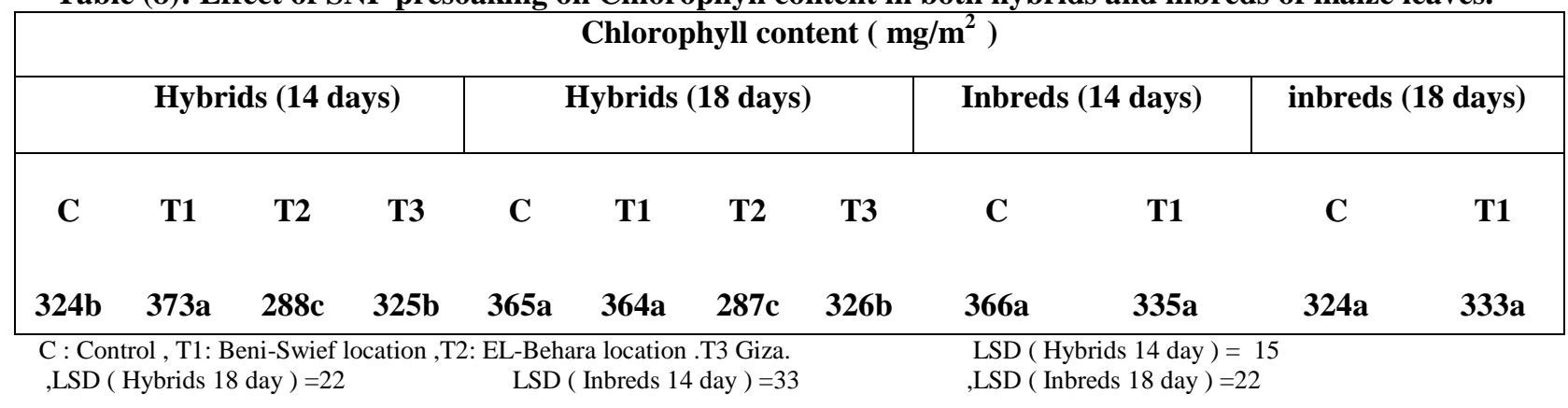

\section{DISCUSSION}

Reactive chemical intermediates derived from various substances have been invoked as causative agents in many toxicological mechanisms. Reactive oxygen species (ROS) are important in biological systems, due to their abundance and interconvertibility (Beligni and Lamattina, 1999 ). As an important member of ROS, $\mathrm{O}^{-}$has been shown to cause direct damage by reacting with proteins containing $\mathrm{Fe}-\mathrm{S}$ clusters, heme groups or $\mathrm{S}-\mathrm{S}$ bonds and oxidize them (Thompson et al., 1987). In this sense, $\mathrm{O}^{-2}$ is devastating to electron transfer in photosynthesis. Furthermore, Rubisco, a key enzyme in carbon assimilation in the stroma of plant chloroplasts is very sensitive to oxidative stress. Oxidative stress causes cross-linking of large subunits of the enzyme by S-S (Mehta et al., 1992). In accord with many other studies, the results from this work indicate that drought stress induced a decrease in GR, GPx and CAT activities
The results of this study indicate that the activity of SOD remained substantially unchanged with SNP-treatment in leaves of both hybrids and inbreds of maize (Tables 1, 2, 3 and 4). These results are in agreement with Unyayar and Cekic (2005) who reported that SOD activity remained substantially unchanged with drought and/or ABA treatments in young leaves of Laurus nobilis $\mathrm{L}$. Other researchers also reported that $\mathrm{ABA}$ treatment or drought increased the activity of SOD in tobacco cell culture (Bueno et al., 1998), mature leaves of Arabidopsis (Jung , 2004), as well as leaves of wheat (Keleb and Oncel, 2002; Tan et al., 2008), maize (Jiang and Zhang, 2002), and sunflower (Keleb and Onyayar, 2004).

In the investigation, it was observed that exogenous NO strongly enhanced some antioxidant enzyme activities (GR, GPx, and CAT) whereas SOD activity did not change in SNP-treated leaves of hybrids and inbreds studied. 
It has been observed in many other plant species that NO stimulates antioxidant enzymes. The inducible effect of the NO donor on the activity of SOD, CAT and APX was observed in rice seedlings (Uchida et al., 2002), and wheat seedling (Tan et al., 2008). The NO donor increased SOD activity in rice under osmotic stress (Cheng et al., 2002) and increased the activities of SOD and CAT in wheat under oxidized stress by paraquat treatment (Hung et al., 2002). Ascorbate, glutathione and nitric oxide decrease under drought stressed leaves of maize, whereas SNP- treatment increased their contents. These results are in agreement with those of other researchers who showed that the GSH biosynthetic pathway is stimulated in response to NO in Medicago truncatula root (Innocenti et al., 2007). Also Sofo et al. (2005) found evidence of changes in antioxidant compounds such as ascorbate and glutathione pools in protecting cellular apparatus during water deficit conditions. When most plants including halophytes are faced with environmental stresses like drought and salt stress, they accumulate low molecular weights of organic substances such as proline (Çiçek and Cakirlar 2002, Christopher and Tony 2008). The accumulation of compatible solutes may help to maintain the relatively high water content necessary for growth and cellular function. It was found that presoaking with SNP causes an increase in osmolality in hybrids at 14 and18 days after sowing. The higher percentage of osmolality was in T3 (14 days) and T2 (18 days) . 9Also, there was a non significant increase in osmolality in inbreds in T1. (14 and 18 day).

Parrish et al., (2006) reported that sunflower seedlings under water stress had lower chlorophyll, soluble protein and total polar lipid content compared to controls. In the present study it was observed that SNP-presoaking caused an increase in the total chlorophyll in hybrids in T1 and prevented the decrease in chlorophyll in inbreds in $\mathrm{T} 1$.

The present results highlight the capacity of maize hybrids and inbreds to withstand drought conditions by regulating the ascorbate-glutathione cycle. The results obtained underline the important role of some antioxidant enzymes and compounds in protecting cellular apparatus during water deficit conditions. In conclusion, experimental evidence obtained indicates that exogenous NO is involved in alleviation of drought stress-induced oxidative damage and stimulation of antioxidant enzymes and antioxidant compounds accumulation in maize leaves under drought stress. Also, exogenous NO can simulate and increase osmolality in leaves of maize and prevent decrease in chlorophyll content.

It could be suggested that the hybrids of maize are more drought tolerant than inbreds. Rewatering after 14 days is better than after 18 days in all hybrids and inbreds. The best locations for maize cultivation are $\mathrm{T} 2$ and $\mathrm{T} 3$ in both hybrids and inbreds. The best location for cultivation at 18 days was $\mathrm{T} 3$ in all hybrids and inbreds. Owing to the ability of NO to reduce oxidative damage and simulate antioxidant compounds accumulation in order to get an insight into the function of $\mathrm{NO}$ in alleviating damage caused by drought stress, further research is needed to focus on the role of molecular biology approach to show the differences between inbred and hybrids of maize in response to drought and SNP treatment.

\section{Acknowledgement}

The authors are greatly indebted to Dr. Mahmoud M. A. Prof. of Agricultural Biochemistry, Fac. of Agric. Cairo Univ. for his valuable help. Also, Ministry of Agriculture for financial support for the project research and technical support by maize Dept. Institute of Agronomy Research, (A C R).

\section{REFERENCES}

Aebi H.E. (1983). Catalase. In: Methods of Enzymatic Analysis, Bergmeyer J., Grabi M., Eds. Verlag Chemie. Weinheim 3: 273-286.

Akataş L., Turkyilmaz B. , Akca H. and Parlak S. (2007). Role of abcisic acid and proline treatment on induction of antioxidant enzyme activities and drought tolerance responses of Laurus nobilis L. seedling. Fen Bilimleri Dergisi , 28:14-26.

Asada K. (1999). The water-water cycle in chloroplasts: scavenging of active oxygen's and dissipation of excess photons, Annu. Rev. Plant Physiol. 50 : 601-639.

Beligni M.V. and. Lamattina L. (1999). Nitric oxide counteracts cytotoxic process mediated by reactive species in plant tissue. Planta, 208: 337-344.

Beyer W. and Fridowich I. (1987) . Assaying for superoxide dismutase activity: Some large consequences of minor changes in conditions. Anal. Biochem. 161: 559-566.

Bowler C., Van Montagu M. and Inze D. (1992). Superoxide dismutase and stress tolerance. Ann. Rev. Plant Physiol. 43: 83-116. 
Bray E., (1993). Molecular responses to water deficit. Plant Physiol., 103: 1035-1040.

Bueno P., Piqueras A. and Kurepa J. (1998). Expression of antioxidant enzymes in response to abscisic acid and high osmoticum in tobacco by 2 cell cultures. Plant Science 138: 27-34.

Carlberg B. and Mannervik I. (1985). Glutathione reductase, Methods Enzymol.113: 484-490.

Chaves M., Maroco J . and Pereira J. (2003). Understanding plant responses to Drought from genes to the whole plant, Funct. Plant Biol. 30: 239-264.

Cheng F.Y., Hsu S.Y and Kao C.H. (2002). Nitric oxide counteracts the senescence of detached rice leaves induced by dehydration and polyethylene glycol but not by sorbitol. Plant Growth Regulation 38: 265-272.

Christopher R. and Tony J. ( 2008). Maize drought tolerance: Potential improvements through arbuscular mycorrhizal symbiosis. Field Crops Research $108: 14-31$.

Çicek N. and Cakirlar H. (2002). The effect of salinity on some physiological parameters in two maize cultivars. BULG. J. Plant Physiology , $28: 66-74$

Parrish D.J. Ervin E. Seiler J. (2006) Studied with Triazoles To Alleviate Drought Stress In Greenhouse-Grown Maize Seedlings. M.S. Thesis, Faculty of Virginia Polytechnic Institute and State University.

Delledonne M., Xia Y.J., Dixon R.A. and Lamb C. (1998). Nitric oxide functions as a signal in plant disease resistance.-Nature., 394: 585-588.

Foyer H., Rowell J. and Walker D. (1983) Measurement of the ascorbate content of spinach leaf protoplasts and chloroplasts during illumination, Planta 157: 239-244.

Foyer H., Theodoulou F. and Delrot S. (2001). The functions of inter- and intracellular glutathione transport systems in plants, Trends Plant Sci.6 (10): 486- 492.

Horemans C., Foyer H. and Asard, H. (2000). Transport and action of ascorbate at the plant plasma membrane, Trends Plant Sci. 5 (6): 263-267.

Hsu Y.T. and Kao C.H. (2004). Cadmium toxicity is reduced by nitric oxide in rice leaves. Plant Growth Regul., 42: 227-238.

Hung K.T., Chang C.J. and Kao. C.H. (2002). Paraquat toxicity is reduced by nitric oxide in rice leaves. J. Plant Physiol. 159:159166.
Hu X, Fang J, Cai W. and Tang , Z. (2003). NOmediated hypersensitive responses of rice suspension cultures induced by incompatible elicitor. Chinese Science Bulletin 48 : 358-363.

Hu X., Zhang A., Zhang J.and Jiang M. (2006). Abscisic acid is a key inducer of hydrogen peroxide production in leaves of maize plants exposed to water stress. Plant Cell Physiology, 47 (11): 1484-1459.

Innocenti G., Pucciariello C., Le Gleuher M. Hopkins J., Stefano M., Delledonne M., Puppo A., Baudouin E. and Frendo P. (2007). Glutathione synthesis is regulated in Medicago truucatula roots. Planta 225: 1597-1602.

Jiang M. and Zhang J. (2002). Involvement of plasma-membrane NADPH oxidase in abscisic acid and water stress-induced antioxidant defense in leaves of maize seedlings. Planta 215: 1022-1030.

Jones M. and Turner C. (1978) Osmotic adjustment in leaves of Sorghum in response to water deficits. Plant Physiol., 61: $122-126$.

Jung S. (2004). Variation in antioxidant metabolism of young and mature leaves of Arabidopsis thaliana subjected to drought. Plant Science 166: 459-466.

Keleb Y. and Oncel I. (2002). Response of antioxidative defense system to temperature and water stress combinations in wheat seedlings. Plant Science 163: 783-790.

Keleb Y. and Onyayar S. (2004). Responses of antioxidant defence system of Helianthus annuus to abscisic acid treatment under drought and water logging. Acta Physiologiae Plantarum 26: 149-156.

Li L., Van Staden J. and Jager A.K. (1998). Effects of plant growth regulators on the antioxidant system in seedlings of two maize cultivars subjected to water stresses. Plant Growth Regulation, 25: 81-87.

Lipton S.A., Yun-Beom Ch., Pan Z.H., Lei S.Z., Vincent H.S., Chen N.J., Sucher J., Loscalzo J. and Stamler J.S. (1993). A redox-based mechanism for the neuroprotective. neurodestructive effects of nitric oxide and related nitroso-compounds. Nature., 364: 626-632.

Maggio A., Myyasaki S.and Veronese, P. (2002) Does proline accumulation play an active role in stress-induced growth reduction? Plant J., 31: 699-712. 
Mata G. and Lamattina L. (2001). Nitric oxide induces stomatal closure and enhances the adaptive plant responses against drought stress. Plant Physiol., 126: 1196-1204.

Mehlhorn H., Lelandais M., Korth H.G. and Foyer, C.H. (1996). Ascorbate is the natural substrate for plant peroxidases, FEBS Lett. 378: 203-206.

Mehta R.A., Fawcett T.W., Porath D. and. Mattoo A.K. (1992). Oxidative stress causes rapid membrane translocation and in vivo degradation of ribulose-1,5-biphosphate carboxylase/oxygenase. J. Biol. Chem, 267: 2810-2816.

Neill S.J., Desikan R. and Hancock J. ( 2003). Nitric oxide signaling in plants. New Physiol., 159: 11-35.

Noctor G. and Foyer C. (1998). Ascorbate and glutathione: keeping active oxygen under control. Annu. Rev. Plant Physiol. 49 :249 279.

Paglia D.E. and Valentine W.N. (1967). Studies on the quantitative and qualitative characterization of erythrocyte glutathione peroxidase. Journal of Laboratory and Clinical Medicine, 70:158-69.

Sharma P. and. Dubey R.S. (2005). Drought induces oxidative stress and enhances the activities of antioxidant enzymes in growing rice seedlings. Plant Growth Regul., 46: 209-221.

Shi S., Wang G., Wang Y. and Zhang L. (2005). Protective effect of nitric oxide against. oxidative stress under ultraviolet- $\beta$ radiation.-Nitric Oxide. 13(1): 1-9.

Smirnoff N. (1993). The role of active oxygen in the response to water deficit and desiccation. New Phytol. $125: 27-58$.

Sofo A., Tuzio A., Dicho B. and Xiloyannis C. (2005). Influence of water deficit and rewatering on the components of the ascorbate-glutathione cycle in four interspecific Prunus hybrids. Plant Science $169: 403-412$.

Tan J., Zhao H., Hong J., Han Y., Li H. and Zaho W. (2008). Effects of exogenous nitric oxide on photosynthesis, antioxidant capacity and proline accumulation in wheat seedling subjected to osmotic stress. World Journal of Agricultural Science 4 (3):307313.

Thompson J.E., Legge R.L. and. Barker R.F. (1987). The role of free radicals in senescence and wounding. New Phytol., 105: 317-344.

Uchida A., Jagendorf A., Hibino T. and Takabe T. (2002). Effects of hydrogen peroxide and nitric oxide on both salt and heat stress tolerance in rice. Plant Sci., 163: 515-523.

Unyayar S. and Cekic F. (2005). Changes in antioxidative enzymes of young and mature leaves of tomato seedlings under drought stress. Turk. J. Biol. 29: 211-216.

Wintermans J. and De Mots A. (1965). Spectrophotometric characteristics of chlorophylls $\mathrm{a}$ and $\mathrm{b}$ and their pheophytins in ethanol. Biochem. Biophys. Acta, 109:448-453.

Van Breusegem F., Vranova J.F. and Dat-Inze D. (2001). The role of active oxygen species in plant signal transduction. Plant Sci., 161: 405-414.

Vranova E., Inze D. and Van Breusegem F. (2002) Signal transduction during oxidative stress. J. Exp. Bot. 53 (372) 1227-1236.

Yang J., Yun J., Zhang T. and Zhao H. (2006). Presoaking with nitric oxide donor SNP alleviates heat shock damage in mung bean leaf discs. Botanical Studies 47:129-136.

\footnotetext{
تأثير اكسيد النتريك على تحسين تحمل سبعة هجن وسبع سلالات من الأرة الثامية للجفاف$$
\text { حسن محمد رشـاد - فاتن محمد ابوالعلاء }
$$$$
\text { قسم النبات الزراعي - فرع فسيولوجيا النبات ـ * قسم الكيمياء الحيوية الزراعية }
$$$$
\text { كلية الزراعة - جامعة القاهرة- الجيزة - مصر التر }
$$$$
\text { يعتبر اكسيد النتريك من المركبات الهامة التى لها دور في تغيير مدى استجابة النبات الفسيولوجية للإجهاد البيئي مثل }
$$

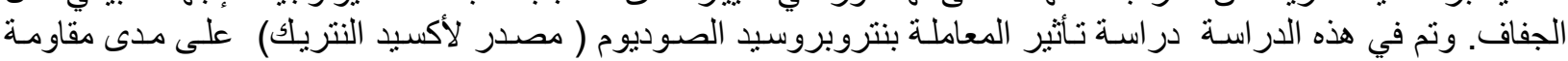


نباتات الذرة للجفاف وذللك بنقع بذور سبعة هجن وسبع سلالات مختلفة من الذرة الثامية في محلول نتروبرو فئروسيد الصوديوم

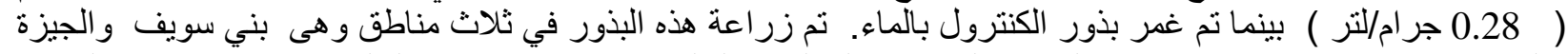

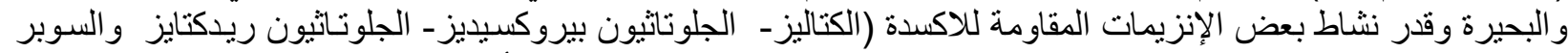

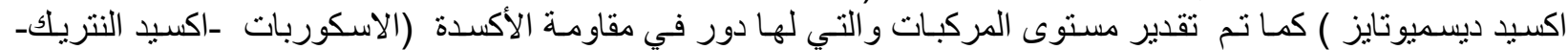

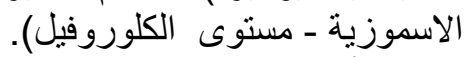

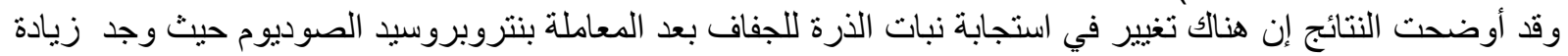

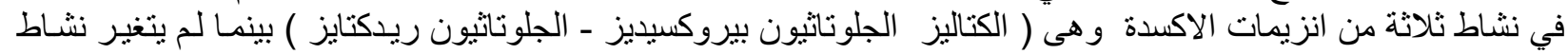

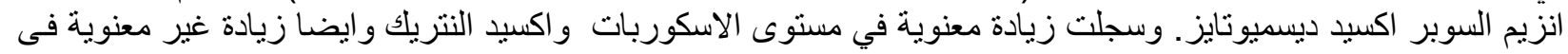

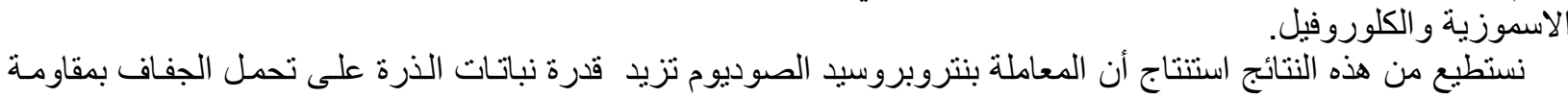

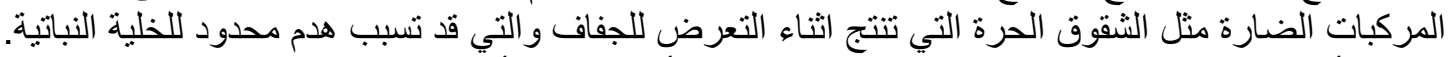

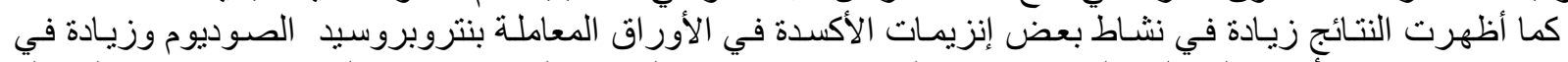

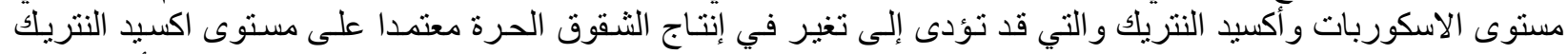

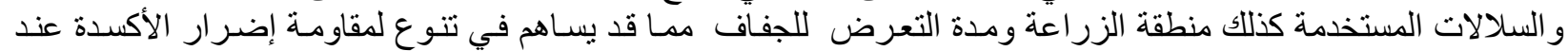

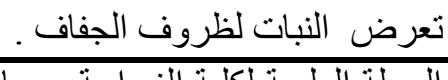
المجلة العلمية لكلية الزراعة - جامعة القاهرة - المجلد (60) العدد الر ابع (أكتوبر 2009 ):398-407. 